\title{
ONTOLOGI DESENTRALISASI FISKAL DALAM NEGARA KESATUAN
}

\author{
Sofyan Hadi \\ Tomy M. Saragih \\ Fakultas Hukum Universitas 17 Agustus 1945 Surabaya \\ e-mail:sofianlaw@yahoo.com
}

\begin{abstract}
ABSTRAK
Konsekuensi dari pelaksanaan otonomi daerah di Indonesia adalah adanya pembagian kewenangan antara pemerintah pusat dengan pemerintah daerah (bidang moneter dan fiskal nasional yang didesentralisasikan kepada daerah). Padahal secara nyata bahwa masalah fiskal dan moneter merupakan urusan absolut pemerintah pusat. Daerah hanya boleh melakukan urusan fiskal melalui dekonsentrasi dan tugas pembantuan. Untuk pemerataan pembangunan di daerah, sebaiknya pemerintah pusat tetap memegang kendali atas sumber-sumber pendapatan yang penting dan strategis, agar dapat diberikan ke daerah lain yang sumber pendapatannya masih minim.
\end{abstract}

Kata Kunci: fiskal, kesatuan, dekonsentrasi, desentralisasi.

\begin{abstract}
Consequences of the implementation of regional autonomy in Indonesia is the division of authority between the central government and the local government (the monetary and national fiscal decentralized). Though obviously that is a matter of fiscal and monetary affairs absolute central government. Area should only be done through the fiscal affairs of deconcentration. For equitable development in the region, the central government should retain control of the sources of revenue and strategic importance, that can be given to other areas of the source of income is still minimal.
\end{abstract}

Keywords: fiscal, unity, deconcentration, decentralization.

\section{PENDAHULUAN}

Salah satu hasil dari perubahan Undang-Undang Dasar 1945 (selanjutnya disebut UUD 1945) yang paling mendasar adalah masalah hubungan antara pusat dan daerah. Mengenai hal ini telah ditetapkan bahwa dalam Negara Kesatuan Republik Indonesia, hubungan pusat dan daerah dilaksanakan berdasarkan prinsip otonomi. Dalam artian bahwa daerah diberikan hak dan wewenang utuk mengatur urusan-urusan yang sesuai dengan kebutuhan daerah masing-masing. Akan tetapi, kebebasan tersebut harus ada batasannya yaitu tetap berpegang pada prinsip negara kesatuan, dimana bahwa dalam negara kesatuan hanya pemerintah pusat yang berdaulat dan kedaulatan tersebut tidak bisa dibagi-bagi (M. Solly Lubis, 1983:8).

Konsekuensi dari pelaksanaan otonomi daerah di Indonesia adalah adanya pembagian kewenangan antara pemerintah pusat dengan pemerintah daerah. Hampir seluruh kewenangan dari pemerintah pusat diserahkan pada daerah, kecuali bidang politik luar negeri, pertahanan keamanan, yustisi, moneter dan fiskal nasional dan agama sebagaimana ditentukan dalam Pasal 10 ayat (3) Undang-Undang Nomor 32 Tahun 2004 tentang Pemerintahan Daerah (yang selanjutnya disebut UU No. 32 Tahun 2004). Hal ini menimbulkan peningkatan terhadap tanggung jawab penyelenggaraan pemerintahan (penyediaan barang publik dan pembangunan ekonomi) di tingkat daerah yang sangat besar (I Gde Pantja Astawa, 2009:55). Kewenangan-kewenangan pemerintah pusat tersebut adalah bersifat absolut, artinya bahwa kewenangan tersebut hanya dimiliki oleh pemerintah pusat dan tidak bisa didesentralisasikan. Hal ini disebabkan oleh sifat dari kewenangan tersebut yaitu dampaknya bersifat nasional (H.A.W. Widjaya, 2005:44).

Permasalahan utama yang menjadi pembahasan dalam tulisan ini adalah berkaitan dengan kewenangan pemerintah pusat dalam bidang moneter dan fiskal nasional yang didesentralisasikan kepada daerah (Sri Winarsih, 2010:31). Secara nyata masalah fiskal dan moneter merupakan urusan absolut dari pemerintah pusat. Daerah hanya boleh melakukan urusan fiskal melalui dekonsentrasi dan tugas pembantuan. 
Sebagai sebuah negara kesatuan, tentunya urusan masalah fiskal itu merupakan masalah yang sangat penting dan mendasar dalam urusan penyelenggaraan negara. Masalah kebijakan fiskal itu juga merupakan urusan atau kewenangan pemerintah pusat. Akan tetapi di dalam beberapa hal, sebagai konsekuensi dari diterapkannya otonomi suatu daerah, maka sudah sepantasnya daerah juga diberikan kewenangan dalam masalah keuangan untuk menunjang pembangunan di daerah bersangkutan. Akan tetapi, permasalahan yang muncul apakah dengan desentralisasi fiskal (http://www.fiskal.depkeu.go.id/2010, diunduh 27 Agustus 2013) tersebut tidak memunculkan dampak negatif bagi keberlangsungan sebuah negara kesatuan seperti Indonesia.

Banyak kekhawatiran yang ada, dengan adanya desentralisasi fiskal justru nantinya akan membuat daerah merasa seperti sebuah negara kecil yang dapat melaksanakan sekehendaknya, tanpa memiliki keterkaitan dengan pemerintah pusat atau daerah lainnya. Tentunya hal tersebut akan mengancam konsep negara kesatuan yang kita anut.

\section{PEMBAHASAN}

\section{Negara Kesatuan dan Otonomi Daerah}

Pada saat sekarang ini suatu negara kesatuan dapat dibedakan dalam dua bentuk, yaitu negara kesatuan dengan sistem sentralisasi, serta negara kesatuan dengan sistem desentralisasi (Edie Toet Hendratno, 2009:46). Dalam negara kesatuan dengan sistem sentralisasi segala sesuatu dalam negara langsung diatur dan diurus oleh pemerintah pusat dan daerahdaerah hanya tinggal melaksanakan saja segala apa yang telah diinstruksikan oleh pusat itu (Edie Toet Hendratno, 2009:46-47). Sedangkan dalam negara kesatuan dengan sistem desentralisasi, kepada daerahdaerah diberikan kekuasaan untuk mengatur dan mengurus rumah tangganya sendiri yang kemudian melahirkan atau dibentuknya daerah-daerah otonom, yaitu merupakan suatu kesatuan masyarakat hukum yang mempunyai batas wilayah tertentu yang berhak, berwenang dan berkewajiban mengatur dan mengurus rumah tangganya sendiri (Soehino, 2000:225).

Zulfikar Salahuddin, Al Chaidar, Herdi Sahrasad menyatakan bahwa model negara kesatuan asumsi dasarnya mempunyai perbedaan secara diametrik dari negara-negara federal. Formasi negara kesatuan dideklarasikan saat kemerdekaan oleh para pendiri negara dengan mengklaim seluruh wilayahnya sebagai bagian dari satu negara (Ni'matul Huda, 2005:92). Tidak ada kesepakatan para penguasa apalagi negaranegara, karena diasumsikan bahwa semua wilayah yang termasuk di dalamnya bukanlah bagian-bagian wilayah yang bersifat independen. Dengan dasar itu, maka negara membentuk daerah-daerah atau wilayah-wilayah yang kemudian diberi kekuasaan atau kewenangan oleh pemerintah pusat untuk bisa mengurus berbagai kepentingan masyarakatnya, ini diasumsikan bahwa negaralah yang menjadi sumber kekuasaannya (Ni'matul Huda, 2005:92).

Menurut C.F. Strong, bahwa esensi dari negara kesatuan adalah negara yang kedaulatannya (the souvereignty) tidak terbagi-bagi, atau dengan kata lain, kekuasaan pusatnya tak terbatas (unrestricted) karena konstitusi negara kesatuan tidak mengakui adanya badan pembentuk undang-undang selain dari badan pembentuk undang-undang pusat (Edie Toet Hendratno, 2009:48).

Adapun hubungannya asas desentralisasi dengan sistem otonomi daerah sebagaimana dikemukakan oleh Benyamin Hossein yang kemudian diikuti oleh pendapat Philip Mowhod dan kemudian disimpulkan oleh Jayadi N.K. dalam Siswanto Sunarno adalah sebagai berikut, secara teoritis desentralisasi adalah pembentukan daerah otonom dan/atau penyerahan wewenang tertentu kepadanya oleh pemerintah pusat. Philip Mawhod menyatakan bahwa desentraliasi ialah pembagian dari sebagian kekuasaan dari pemerintah oleh kelompok-kelompok yang berkuasa di pusat terhadap kelompok-kelompok lain yang masingmasing memiliki otoritas di dalam wilayah tertentu di suatu negara. Dari defenisi kedua pakar di atas, menurut Jayadi N.K. mengandung empat pengertian: pertama, desentralisasi merupakan pembentukan daerah otonom; kedua, daerah otonom yang dibentuk diserahi wewenang tertentu oleh pemerintah pusat; ketiga, desentralisasi juga merupakan pemencaran kekuasaan oleh pemerintah pusat; keempat, kekuasaan yang dipencarkan akan diberikan kepada kelompokkelompok masyarakat dalam wilayah-wilayah tertentu (Siswanto Sunarno, 2009:13). Terdapat tiga landasan dasar asas pokok pelaksanaan pemerintahan daerah yang selama ini sering digunakan banyak negara yakni asas desentralisasi, dekonsentrasi, dan asas tugas pembantuan (medebewind).

\section{Asas Desentralisasi}

Pemaknaan dari asas desentralisasi itu menjadi perdebatan di kalangan para pakar, dari pemaknaan para pakar tersebut Agus Salim Andi Gadjong telah mengklasifikasikan desentralisasi sebagai berikut: yaitu Desentralisasi sebagai penyerahan dari sebuah kewenangan dan kekuasaan dari pusat ke daerah; Desentralisasi sebagai pelimpahan kekuasaan dan 
kewenangan; dan Desentralisasi sebagai pembagian, penyebaran, pemencaran, dan pemberian kekuasan dan kewenangan; Desentralisasi sebagai sarana dalam pembagian dan pembentukan daerah pemerintahan. (Agus Salim Andi Gadjong, 2007:79)

Logeman telah membagi desentralisasi menjadi (2) dua macam yakni pertama, dekonsentrasi atau desentralisasi jabatan (ambelitjke decentralisatie) yaitu pelimpahan kekuasaan dari tingkatan lebih atas kepada bawahannya guna melancarkan pekerjaan di dalam melaksanakan tugas pemerintahan. Kedua, yaitu desentralisasi ketatanegaraan (staatkundige decentralisatie) pelimpahan kekuasaan perundangan dan pemerintahan kepada daerah-daerah otonom di dalam lingkungannya, dari desentralisasi ini dapat dibagi dalam dua macam yakni desentralisasi teritorial dan desentralisasi fungsional.

Desentralisasi teritorial itu merupakan penyerahan kekuasaan untuk mengatur dan mengurus rumah tangganya sendiri (otonom) dan batas pengaturan termaksud adalah daerah; sedangkan desentralisasi fungsional itu adalah penyerahan kekuasaan untuk mengatur dan mengurus fungsi tertentu dan batas pengaturan termaksud adalah jenis dan fungsi itu sendiri.

A.H. Manson membagi desentralisasi menjadi 2 bagian yaitu: desentralisasi politik dan desentralisasi administratif (desentralisasi birokrasi). Desentralisasi politik disebut devolusi, sedangkan desentralisasi administratif disebut dengan dekonsentrasi. Menurut Koesoemaatmaja bahwa desentralisasi ketatanegaraan atau politik merupakan suatu pelimpahan kekuasaan perundangan dan pemerintah kepada daerah-daerah otonom di lingkungannya dengan mempergunakan saluran-saluran tertentu (perwakilan) ikut serta dalam pemerintahan dengan batas wilayah daerah masingmasing (Agus Salim Andi Gadjong, 2007:5).

Dalam aspek hubungan desentralisasi dengan demokrasi, menurut pendapat Mohammad Yamin meletakkan desentralisasi sebagai syarat demokrasi karena konstitusi disusun dalam kerangka negara kesatuan harus tercermin bagi kepentingan daerah, melalui suatu aturan pembagian kekuasaan antara badan-badan pusat dan badan-badan daerah secara adil dan bijaksana sehingga daerah memelihara kepentingannya dalam kerangka negara kesatuan. Susunan yang demokratis membutuhkan pemecahan kekuasaan pemerintahan baik di tingkat pusat dan pembagian kekuasaan antara pusat dan daerah. Disinilah diketengahkan asas desentralisasi dan dekonsentrasi yang akan dapat membendung arus sentralisasi (Moh. Yamin, 1960:168).
Philipus M. Hadjon menyatakan, desentralisasi mengandung makna bahwa wewenang untuk dapat mengatur dan mengurus urusan pemerintahan tidak semata-mata hanya dilakukan oleh pemerintah pusat, melainkan juga oleh satuan-satuan pemerintahan yang lebih rendah, baik dalam bentuk teritorial maupun fungsional. Satuan-satuan pemerintahan yang lebih rendah diserahi dan dibiarkan mengatur dan mengurus sendiri sebagaian urusan pemerintahan. Penyerahan urusan kepada atau membiarkan satuan pemerintahan yang lebih rendah mengatur dan mengurus urusan pemerintahan tertentu dapat bersifat penuh dan tidak penuh. Penuh kalau penyerahan atau membiarkan mencakup wewenang untuk mengatur dan mengurus baik baik asas maupun cara menjalankannya. Tidak penuh, kalau hanya terbatas pada wewenang untuk dapat mengatur dan mengurus cara menjalankannya (Philipus M. Hadjon, 2008:112).

Pendelegasian wewenang dalam desentralisasi bersifat hak dalam menciptakan peraturan-peraturan dan keputusan-keputusan penyelenggaraan lainnya di dalam batas-batas urusan yang telah diserahkan kepada badan-badan otonom itu. Jadi, pendelegasian wewenang dalam desentralisasi berlangsung antara lembaga-lembaga di pusat dengan lembaga-lembaga otonom di daerah, sementara pendelegasian dalam dekonsentrasi berlangsung antara petugas perorangan pusat di daerah.

\section{Asas Dekonsentrasi}

Dekonsentrasi adalah suatu pelimpahan wewenang dari pemerintahan kepada daerah otonom sebagai wakil pemerintah pusat dan/atau perangkat pusat di daerah dalam kerangka negara kesatuan, dan lembaga yang melimpahkan kewenangan dapat memberikan perintah langsung kepada pejabat yang telah dilimpahi kewenangan mengenai pengambilan atau pembuatan keputusan (Noer Fauzi dan R. Yando Zakaria, 2000: 11). Sebab terjadinya penyerahan wewenang dari pemerintah pusat pada pejabat-pejabat atau aparatnya untuk melaksanakan wewenang tertentu dilakukan dalam rangka menyelenggarakan urusan pemerintah pusat di daerah, sebab pejabat-pejabat atau aparatnya merupakan wakil pemerintah pusat di daerah yang bersangkutan.

Dekonsentrasi ialah merupakan salah satu dari jenis desentralisasi, dekonsentrasi itu sudah pasti desentralisasi, tetapi desentralisasi tidak selalu berarti dekonsentrasi. C.F. Strong mempunyai pendapat bahwa dekonsentrasi merupakan perintah kepada para pejabat pemerintah atau dinas-dinas yang bekerja dalam hierarki dengan suatu badan pemerintahan 
untuk mengindahkan tugas-tugas tertentu dibarengi dengan pemberian hak mengatur dan memutuskan beberapa hal tertentu dengan tanggung jawab terakhir tetap berada pada badan pemerintahan sendiri (A. Syafruddin, 1991:4).

Pendelegasian wewenang kepada dekonsentrasi hanya bersifat menjalankan dan/atau melaksanakan peraturan-peraturan dan keputusan-keputusan pusat lainnya yang tidak berbentuk peraturan, yang tidak dapat berprakarsa menciptakan peraturan dan atau membuat keputusan bentuk lainnya untuk kemudian dilaksanakannya sendiri pula. Pendelegasian dalam dekonstrasi berlangsung antara petugas perorangan pusat di pemerintahan pusat pada petugas perorangan pusat di dalam pemerintahan daerah. Sedangkan menurut Laica Marzuki dekonsentrasi merupakan ambtelijke decentralisastie atau delegative van bevoegdheid, yakni pelimpahan kewenangan dari alat perlengkapan negara di pusat kepada instansi bawahan, guna bisa melaksanakan pekerjaan tertentu dalam penyelenggaraan pemerintahan. Pemerintahan pusat itu tidak kehilangan kewenangannya karena instansi bawahan melaksanakan tugas atas nama pemerintahan pusat. Jadi, dekonsentrasi diartikan bisa sebagai penyebaran atau sebagai pemancaran kewenangan pusat kepada petugasnya yang tersebar di wilayahwilayah untuk melaksanakan kebijaksanaan pusat. Pendelegasian wewenang pada dekonsentrasi hanya mempunyai sifat menjalankan atau melaksanakan peraturan-peraturan dankeputusan-keputusan pusat lainnya yang tidak berbentuk peraturan yang tidak dapat berprakarsa menciptakan peraturan dan atau membuat keputusan bentuk lainnya untuk kemudian dilaksanakan sendiri pula.

Sunindia Ninik Widiyanti berpendapat, bahwa dekonsentrasi ada karena urusan tersebut itu terlalu berat jika dijadikan urusan rumah tangga daerah atau urusan tersebut adalah urusan nasional atau jika urusan termaksud itu dilaksanakan oleh daerah tidak akan tercapai daya dan hasil guna yang tinggi (Philipus M. Hadjon, 2008:114).

\section{Asas Medebewind}

Tugas pembantuan (medebewind) yaitu merupakan keikutsertaan pemerintah daerah untuk melaksanakan urusan pemerintah yang kewenangannya lebih luas dan lebih tinggi di daerah tersebut. Tugas pembantuan adalah salah satu wujud dekonsentrasi, akan tetapi pemerintah tidak membentuk badan sendiri untuk itu, yang tersusun secara vertikal. Jadi medebewind merupakan kewajiban untuk melaksanakan peraturanperaturan yang ruang lingkup dari wewenangnya bercirikan tiga hal, yaitu Materi yang dilaksanakan tidak termasuk rumah tangga daerah-daerah otonom untuk melaksanakannya; Dalam menyelenggarakan pelaksanaannya itu, daerah otonom itu mempunyai kelonggaran untuk menyesuaikan segala sesuatu dengan kekhususan daerahnya sepanjang peraturan tersebut mengharuskannya memberi kemungkinan untuk itu; Yang dapat diserahi urusan medebewind hanya daerah-daerah otonom saja, tidak mungkin alatalat pemerintahan lain yang tersusun secara vertikal (Noer Fauzi dan R.Yando Zakaria, 2000:13).

\section{Kebijakan Fiskal}

Secara etimologi, fiskal berarti berkenaan dengan urusan pajak atau pendapatan negara. Dalam Black Law Dictionary, fiscal dedifinisikan sebagai: 1. of or relating to financial matters (fiscal year); 2. of or relating to public finances or taxation (the city's sound fiscal policy) (Hanry Campbell Black, 1979: 711). Dengan demikian, fiskal itu berkaitan dengan pajak (tax). Adapun tax dalam Black Law Dictionary didefinisikan: "a charge, usu, monetary, imposed by the governemnet on person, entities, transaction, or property to yield public revenue.... Taxes are the enforced proportional contribution from person and property, livied by the state by virtue of its sovereignty for the support of government and for all public needs (Hanry Campbell Black, 1979:1594). Atau dengan kata lain, tax adalah: 1. charge against a citizen's person or property or activity for the support of government, 2. A charge, 3. especially a pecuniary burden which is imposed by authority, 4. levy a tax on, 5. set or determine the amount of (a payment such as a fine), 6. use to the limit, 7. make a charge against or accuse, 8. To subject to the payment of a tax or taxes; to impose a tax upon; to lay a burden upon; especially, to exact money from for the support of government (http://www.artikata.com, diunduh 27 Agustus 2013).

Kebijakan fiskal adalah suatu kebijakan ekonomi dalam rangka mengarahkan kondisi perekonomian untuk menjadi lebih baik dengan jalan mengubah penerimaan dan pengeluaran pemerintah. Kebijakan ini mirip dengan kebijakan moneter untuk mengatur jumlah uang beredar, namun kebijakan fiskal lebih menekankan pada pengaturan pendapatan dan belanja pemerintah.

Instrumen kebijakan fiskal adalah penerimaan dan pengeluaran pemerintah yang berhubungan erat dengan pajak. Dari sisi pajak jelas jika mengubah tarif pajak yang berlaku akan berpengaruh kepada ekonomi. Jika pajak diturunkan maka kemampuan 
daya beli masyarakat akan meningkat dan industri akan dapat juga meningkatkan jumlah output. Dan sebaliknya kenaikan pajak akan menurunkan daya beli masyarakat serta menurunkan output industri secara umum.

Kebijakan anggaran atau politik anggaran dibagi menjadi 3 (tiga) yaitu: Pertama, Anggaran defisit (defisit budget)/kebijakan fiskal ekspansif - anggaran defisit adalah kebijakan pemerintah untuk membuat pengeluaran lebih besar dari pemasukan negara guna memberi stimulus pada perekonomian. Umumnya sangat baik digunakan jika keaadaan ekonomi sedang resesif. Kedua, Anggaran surplus (surplus budget)/ kebijakan fiskal kontraktif - anggaran surplus adalah kebijakan pemerintah untuk membuat pemasukannya lebih besar daripada pengeluarannya. Baiknya politik anggaran surplus dilaksanakan ketika perekonomian pada kondisi yang ekspansi yang mulai memanas untuk menurunkan tekanan terhadap permintaan. Ketiga, Anggaran berimbang (balanced budget). anggaran berimbang ini terjadi ketika pemerintah menetapkan pengeluaran yang sama besar dengan pemasukan. Tujuan politik anggaran berimbang yakni terjadinya kepastian anggaran serta meningkatkan disiplin (http//organisasi.org//Pengertian Kebijakan Moneter dan Fiskal//, diunduh 27 Agustus 2013).

\section{Dampak Desentralisai Fiskal terhadap Bentuk Negara Kesatuan Republik Indonesia}

Konsep susunan negara yang berkaitan dengan bentuk-bentuk negara modern saat ini dapat ditinjau dari segi susunannya. Negara apabila ditinjau dari segi susunan atau bentuk negara, maka akan ditemukan dua jenis bentuk negara, sebagaimana yang dikemukakan oleh Soehino, yaitu bentuk dari negara kesatuan dan bentuk negara federal (Soehino, 2000:224):

Dalam perkembangannya, lebih lanjut juga di beberapa negara kesatuan telah dilaksanakan asas desentralisasi (penyerahan urusan dari pemerintah pusat ke daerah otonom) untuk menjadi urusan rumah daerah otonom itu. Pelaksanaan asas desentralisasi inilah yang melahirkan daerah-daerah otonom. Daerah otonom dapat mengatur rumah tangganya sendiri sesuai dengan peraturan perundang-undangan yang berlaku.

Dalam negara kesatuan, adapun tanggung jawab pelaksanaan atas tugas-tugas pemerintahan itu pada dasarnya tetap berada di tangan pemerintah pusat. Adapun hubungan antara asas desentralisasi dengan sistem otonomi daerah sebagaimana dikemukakan oleh Benyamin Hossein yang kemudian diikuti oleh pendapat Philip Mowhod dan kemudian disimpulkan oleh Jayadi N.K. dalam Siswanto Sunarno adalah sebagai berikut, Secara teoritis desentralisasi seperti yang dikemukakan oleh Benyamin Hossein adalah pembentukan suatu daerah otonom atau penyerahan wewenang yang tertentu kepadanya oleh pemerintah pusat. Philip Mawhod menyatakan desentralisasi adalah pembagian sebagian kekuasaan pemerintah oleh kelompok yang telah berkuasa di pusat terhadap kelompok lain yang masing-masing kelompok itu memiliki otoritas di dalam wilayah tertentu di suatu negara. Dari defenisi kedua pakar di atas, menurut Jayadi N.K. bahwa mengandung empat pengertian: pertama, desentralisasi merupakan pembentukan daerah otonom; kedua, daerah otonom yang dibentuk diserahi wewenang tertentu oleh pemerintah pusat; ketiga, desentralisasi juga merupakan pemencaran kekuasaan oleh pemerintah pusat; keempat, kekuasaan tersebut telah dipencarkan dan diberikan kepada kelompok-kelompok masyarakat di dalam wilayah tertentu (Siswanto Sunarno, 2009:13).

Dari teori di atas dapat diketahui bahwa kekuasaan pemerintahan sesungguhnya tetap berada di tangan pemerintah pusat. Dengan demikian pemerintah pusatlah yang berwenang untuk memberikan atau membagi kewenangan kepada tingkatan pemerintahan yang lebih rendah yaitu pemerintah daerah, baik itu tingkat pemerintahan daerah Propinsi ataupun tingkat pemerintahan daerah Kabupaten atau Kota. Dengan konsep seperti yang disebutkan di atas, maka pembagian urusan pemerintah pusat kepada pemerintah daerah termasuk didalamnya terkait masalah desentralisasi fiskal adalah kewenangan bulat pemerintah pusat yang kemudian dibagi kepada pemerintah daerah melalui peraturan perundangundangan. Negara berbentuk kesatuan seperti Negara Kesatuan Republik Indonesia, pada hakekatnya kekuasaan pemerintahan ada di tangan pemerintah pusat yang dalam hal ini adalah presiden.

Presiden adalah kepala eksekutif sebagaimana yang ditentukan pada Pasal 4 ayat (1) UUD 1945 yaitu bahwa seorang Presiden memegang kekuasaan pemerintahan negara. Akan tetapi jika berdasarkan ketentuan Pasal 18 UUD 1945 menentukan bahwa Negara Kesatuan Republik Indonesia bagi ke dalam tingkatan pemerintahan atau satuan pemerintahan di daerah Propinsi dan pemerintahan di daerah. di Propinsi dibagi lagi atas daerah Kabupaten/Kota yang mana pada tiap daerah tersebut baik pada tingkat Propinsi maupun pada tingkat Kabupaten atau Kota memiliki pemerintahan daerah yang akan mengatur dan mengurus sendiri urusan rumah tangga daerahnya masing-masing (Tomy Michael, 2013:98). 
Dalam konsep otonomi daerah dikenal urusan absolut dan urusan relatif. Urusan absolut adalah merupakan urusan mutlak dari pemerintah pusat sebagai pemegang kedaulatan yang tertinggi dalam sebuah negara. Urusan tersebut tidak dapat dibagi kewenangannya kepada pemerintahan yang lebih rendah, namun hanya pada pemegang kedaulatan yang berwenang untuk melaksanakannya. Urusan absolut tentang pembentukan norma, standar, prosedur maupun ketentuan dipegang oleh pemerintah pusat. Urusan absolut bukan merupakan objek urusan yang dapat didesentralisasikan. Sehingga urusan absolut dapat didekonsentrasikan dan diperbantukan kepada pemerintah daerah. Dalam konteks otonomi daerah di Indonesia, Pasal 10 ayat (3) UU No. 32 Tahun 2004 menentukan bahwa urusan pemerintahan menjadi urusan pemerintah pada ayat (1) meliputi: politik luar negeri, pertahanan, keamanan, yustisi, moneter dan fiskal nasional, agama.

Kelima urusan di atas mutlak menjadi kewenangan pemerintah pusat sebagai pemegang suatu kedaulatan tertinggi negara. Pemerintah pusat tidak dapat lagi mendesentralisasikannya kepada pemerintah daerah. Pemerintah pusat hanya dapat mendekonsentrasikan dan memberikan tugas-tugas pembantuan kepada pemerintahan yang ada di daerah. Norma, standar, prosedur dan ketentuan dari keenam urusan tersebut menjadi kewenangan pemerintah pusat. Dan apabila pemerintah pusat ingin melimpahkan kewenangan tersebut kepada pemerintah daerah, maka daerah hanya berwenang untuk melaksanakannya sesuai dengan norma, standar, prosedur dan ketentuan yang sudah ditetapkan oleh pemerintah pusat.

Sedangkan urusan relatif itu merupakan urusan pemerintah pusat yang dapat dibagi pada pemerintah daerah. Artinya bahwa urusan-urusan tersebut pada hakikatnya adalah urusan untuk pemerintah pusat tapi tidak bersifat absolut, sehingga urusan tersebut dapat disentralisasikan kepada pemerintah daerah. Selain urusan absolut sebagaimana dimaksud dalam Pasal 10 ayat (3) UU No. 32 Tahun 2004, termasuk urusan yang bersifat relatif. Dalam urusan relatif tersebut terdapat hubungan kewenangan antar satuan pemerintahan yakni Pemerintah Pusat, Propinsi dan Kabupaten/ Kota. Hubungan kewenangan tersebut ditentukan dalam Pasal 18A UUD 1945 yaitu yang menentukan: Hubungan wewenang antara Pemerintah Pusat dan pemerintahan daerah Propinsi, Kabupaten, dan Kota atau antara pemerintah Propinsi dan Kabupaten dan Kota diatur dengan dengan undang-undang dengan memperhatikan kekhususan dan keragaman daerah; Hubungan keuangan, pelayanan umum, pemanfaatan sumber daya alam dan sumber daya lainnya antara pemerintah pusat dan pemerintahan daerah diatur dan dilaksanakan secara adil dan selaras berdasarkan undang-undang.

Desentralisasi menjadi ialah sebuah pilihan selain karena ingin dapat mewujudkan pemerintahan yang responsif terhadap dinamika yang terjadi di daerah, juga karena pemerintahan yang desentralistis lebih kondusif bagi percepatan pengembangan demokrasi di Indonesia. Dengan melimpahkan sebagian urusan pemerintahan ke daerah, maka rakyat yang ada di daerah akan menjadi semakin mudah terlibat dalam penyelenggaraan pemerintahan. Mereka juga akan lebih mudah mengawasi jalannya penyelenggaraan pemerintahan. Hubungan antar kewenangan tersebut berimplikasi kepada adanya pembagian kekuasaan yang berdasarkan pada Pasal 11 ayat (1) UU No. 32 Tahun 2004 menentukan bahwa pembagian urusan pemerintahan dibagi berdasarkan kriteria-kreteria eksternalitas, dan akuntabilitas, serta efisiensi dengan memperhatikan keserasian hubungan antar tingkatan dan/atau susunan pemerintahan.

Mengenai pembagian urusan pemerintahan antar susunan pemerintahan telah dikeluarkan Peraturan Pemerintah Republik Indonesia Nomor 38 Tahun 2007 tentang Pembagian Urusan-urusan Pemerintahan yaitu antara Pemerintah Pusat, Pemerintahan Daerah Propinsi, dan Pemerintahan Daerah Kabupaten/Kota (yang selanjutnya akan disebut PP No. 38 Tahun 2007). Pada Pasal 2 ayat (4) PP No. 38 Tahun 2007 menentukan bahwa urusan-urusan di pemerintahan yang dapat dibagi yaitu: a. pendidikan; b. kesehatan; c. pekerjaan umum; d. perumahan; e. penataan ruang; f. perencanaan pembangunan; g. perhubungan; $h$. lingkungan hidup; i. pertanahan; j. kependudukan dan catatan sipil; k. pemberdayaan perempuan dan perlindungan kepada anak; 1. keluarga berencana dan juga keluarga sejahtera; m. sosial; n. ketenagakerjaan dan ketransmigrasian; o. koperasi dan usaha kecil dan menengah; p. penanaman modal; q. kebudayaan dan kepariwisataan; r. kepemudaan dan olah raga; s. kesatuan bangsa dan politik di dalam negeri; t. otonomi daerah, pemerintahan umum, administrasi keuangan yang ada di daerah, perangkat-perangkat daerah, kepegawaian, dan juga masalah persandian; u. pemberdayaan masyarakat dan desa; v. statistik; w. kearsipan; dan x. perpustakaan-perpustakaan; y. komunikasi dan informatika; dan yang terakhir adalah z. pertanian dan ketahanan pangan; yaitu yang merupakan: a. kehutanan; b. energi dan sumber daya mineral; c. kelautan dan perikanan; d. perdagangan; dan e. perindustrian. 
Walaupun dalam Pasal 18 UUD 1945 dan UU No. 32 Tahun 2004 telah ditentukan bahwa ada urusan pemerintahan yang bersifat absolut sebagaimana telah diuraikan di atas, namun demikian urusan absolut tersebut juga ada yang didesentralisasikan kepada pemerintah daerah. Salah satunya adalah urusan fiskal (desentralisasi fiskal). Desentralisasi fiskal dapat didefinisikan sebagai devolusi (penyerahan) tanggung jawab fiskal dari pemerintah pusat kepada tingkatan pemerintahan yang ada dibawahnya (Ani Sri Rahayu, 2010:116). Desentralisasi fiskal juga dapat diartikan sebagai penyerahan urusan fiskal ke bawah, dimana jenjang pemerintahan yang lebih tinggi menyerahkan sebagian kewenangannya mengenai anggaran dan keputusan-keputusan finansial kepada jenjang yang lebih rendah (Ahmad Erani Yustika, 2008:25).

Beberapa masalah-masalah atau pun hal-hal yang terkait dengan desentralisasi fiskal diantaranya ialah: Pertama, Pembagian peran dan tanggung jawab antar pemerintah. Pembagian peran dan tanggung jawab antar pemerintah pusat dan antar pemerintah daerah merupakan landasan pokok bagi penerapan desentralisasi fiskal. Dengan adanya pengaturan yang tegas mengenai kewenangan, peran dan tanggung jawab masing-masing tingkatan pemerintahan yaitu tingkat pemerintah pusat, tingkat pemerintah daerah Propinsi dan tingkat pemerintah daerah Kabupaten/ Kota maka akan terciptanya suatu keteraturan dan keharmonisan hubungan antar tingkat pemerintahan tersebut dalam menjalankan kewenangannya masingmasing. Selain dari itu, kewenangan pemerintah pusat dalam bidang fiskal harus tetap memiliki porsi yang besar sehingga konsep pengawasan dan konsep bentuk negara kesatuan tetap terjaga.

Kedua, Tingkat pemerintahan yang mana yang harus mendesain dan menjalankan seluruh aturan. Dalam perjalanan otonomi daerah di Indonesia dewasa ini, pemerintah daerah memiliki kewenangan untuk membuat perutaran daerah untuk melaksanakan tugas otonomi dan untuk menjalankan perintah peraturan perundang-undangan yang lebih tinggi sebagaimana yang dimaksud pada Pasal 18 ayat (5) UUD 1945. Dengan kewenangan yang dimilikinya tersebut maka pemerintah daerah dapat mendesain dan menjalankan peraturan daerah yang dibuat untuk melaksanakan tugas otonomi dan untuk melaksanakan perintah peraturan perundang-undangan yang lebih tinggi.

Dalam hal pajak daerah di Indonesia telah diatur oleh undang-undang tersendiri yaitu Undang-Undang Republik Indonesia Nomor 28 Tahun 2009 tentang Pajak Daerah dan Retribusi Daerah (yang selanjutnya disebut UU No. 28 Tahun 2009) sebagai pengganti
UU No. 34 Tahun 2000 dan Undang-Undang Republik Indonesia Nomor 18 Tahun 1997.

Pemerintah pusat tetap memegang kendali atas segala bentuk-bentuk peraturan perundang-undangan, sehingga apabila ada peraturan daerah yang dinilai bertentangan dengan suatu peraturan perundanganundangan yang lebih tinggi, maka pemerintah pusat dapat membatalkan peraturan di daerah tersebut. Oleh karena itu, UU No. 28 Tahun 2009 haruslah menyebutkan secara rinci dan jelas mengenai bidang apa saja yang boleh diatur dalam peraturan daerah sehingga perbedaan yang terlalu mencolok antara daerah yang satu dengan daerah yang lainnya dapat dihindari.

Dengan demikian, maka dalam segala tingkat pemerintahan yang ada memiliki kewenangan untuk mendesain dan menjalankan jenis aturan teretentu yang berkaitan dengan kebijakan-kebijakan fiskal. Misalnya pemerintah pusat berwenang mendesain dan menjalankan serta mengawasi suatu undang-undang tentang pajak daerah dan retribusi daerah. Sebagai contoh, misalnya sebuah daerah menetapkan peraturan daerah tentang pajak daerah dan retribusi daerah yang dianggap bertentangan dengan peraturan perundangundangan yang lebih tinggi, maka pemerintah pusat dapat membatalkan keberlakuan dari sebagian atau seluruh peraturan daerah yang dinilai bertentangan dengan peraturan perundang-undangan yang lebih tinggi, hal tersebut termasuk dalam kewenangan pemerintah pusat dalam bidang pengawasan peraturan daerah secara preventif.

Sebagaimana telah dijelaskan di atas bahwa dalam suatu negara yang berbentuk kesatuan seperti halnya Indonesia, pada hakekatnya kekuasaan pemerintahan hanya ada di tangan pemerintah pusat yang dalam hal ini adalah Presiden. Sebagaimana yang ditentukan pada Pasal 4 ayat (1) UUD 1945 yaitu bahwa Presiden memegang kekuasaan pemerintahan negara. Akan tetapi berdasarkan ketentuan Pasal 18 UUD 1945 yang menentukan bahwa Negara Kesatuan Republik Indonesia dibagi ke dalam tingkatan pemerintahan atau satuan pemerintahan daerah Propinsi dan Daerah. Propinsi dibagi atas Kabupaten dan Kota yang mana pada tiap daerah tersebut baik pada tingkat Propinsi maupun Kabupaten/Kota memiliki pemerintahan daerah yang mengatur dan mengurus sendiri urusan rumah tangga daerahnya masing-masing.

Kewenangan yang diberikan oleh undang-undang pada pemerintah daerah juga harus disertakan dengan sumber-sumber pembiayaan yang akan digunakan untuk membiayai urusan pemerintahannya tersebut. Konsekuensi dari adanya pembagian kewenangan 
tersebut adalah diserahkannya beberapa sumber dari pendapatan kepada daerah untuk membiayai urusan pemerintahannya tadi.

Secara teoritik, ada 4 (empat) jenis pendekatan hubungan keuangan antara di pusat dan di daerah sebagai akibat dari dilaksanakannya sistem otonomi daerah, yaitu sebagai berikut: Pertama, Pendekatan kapitalisasi (permodalan), dalam jenis pendekatan ini dapat dilakukan beberapa cara untuk memberikan sumber pembiayaan bagi pemerintah daerah untuk dapat menjalankan pemerintahannya yaitu sebagai berikut: a. Daerah memperoleh modal permulaan yang diharapkan untuk bisa diinvestasikan; $b$. Modal merupakan pemberian pemerintah pusat dalam bentuk bantuan; c. Modal itu dapat juga berbentuk barang. Kedua, Pendekatan pendapatan: a. Daerah diberikan sumber pendapatan; b. Daerah diberikan hak untuk mengelola sejumlah urusan untuk menjadi sumber pendapatan. Ketiga, Pendekatan pengeluaran, yaitu dapat dilaksanakan dengan cara pemerintah pusat memberikan sejumlah dana pinjaman, dan bantuan (sumbangan) atau bagi hasil pungutan kepada daerah untuk membiayai pengeluaran tertentu. Keempat, Pendekatan komprehensif, yaitu merupakan gabungan dari 3 (tiga) jenis pendekatan sebelumnya (Emanuel Sujatmoko, 2010).

Konsekuensi adanya pembagian kewenangan dalam penyelenggaraan urusan pemerintahan, yaitu dengan adanya kebijakan-kebijakan desentralisasi urusan pemerintahan diikuti dengan memberikan sumber pembiayaan kepada pemerintah daerah untuk penyelenggaraan urusan pemerintahan yang ada di daerah. Sumber keuangan yang telah diberikan kepada daerah tersebut juga dapat disertai dengan memberikan suatu kewenangan pada daerah otonom untuk mengelola sumber-sumber pendapatan tersebut. Dengan adanya kewenangan untuk mengelola sumber pendapatan sebagai sumber pembiayaan dalam penyelenggaraan urusan pemerintahan di daerah, maka tujuan dari dilaksanakannya suatu sistem otonomi daerah dapat tercapai.

Dari pemaparan tersebut di atas maka, secara teoritik desentralisasi fiskal itu sangat diperlukan untuk keperluan pembangunan suatu daerah sebagai akibat dari diserahkannya dari berbagai jenis urusan pemerintahan kepada pemerintah daerah. Dengan kata lain, urusan pemerintahan yang akan diarasakan secara langsung oleh rakyat adalah berada di tingkat pemerintah daerah sehingga pembiayaannya untuk penyelenggaraan urusan tersebut memang sewajarnya dikelola oleh pemerintah daerah itu sendiri sehingga memudahkan untuk pengelolaannya.
Berdasarkan pendekatan pendapatannya di atas maka dalam konteks keIndonesiaan telah dilakukan berbagai jenis kebijakan yaitu dengan memberikan sumber-sumber pendapatan kepada pemerintah daerah sebagaimana yang diatur pada Pasal 157 UU No. 32 Tahun 2004 serta juga terdapat pada Undang-Undang Republik Indonesia Nomor 33 Tahun 2004 tentang Perimbangan Keuangan antara Pemerintah Pusat dan Pemerintah Daerah (yang selanjutnya disebut UU No. 33 Tahun 2004). Hal yang bersifat teknis juga dapat dilihat dari ketentuan UU No. 34 Tahun 2000 dan Peraturan Pemerintah Republik Indonesia Nomor 66 Tahun 2001 tentang Retribusi Daerah dan telah diganti dengan diberlakukannya UU No. 28 Tahun 2009.

Konsep negara kesatuan menempatkan pemerintah pusat sebagai pemegang kekuasaan pemerintahan tertinggi dalam negara. Kewenangan pemerintah pusat yang walaupun menurut Pasal 10 ayat (3) UU No. 32 Tahun 2004 hanya pada 6 (enam) bidang tertentu saja, akan tetapi juga mencakup seluruh kewenangan lain yang dilaksanakan untuk penyelenggaraan negara. Walaupun pemerintah pusat menyerahkan sebagian kewenangan yang dimilikinya untuk menjadi urusan dari pemerintah daerah, bukan berarti pemerintah pusat tidak dapat mencampuri ataupun mengawasi jalannya penyelenggaraan otonomi daerah tersebut, sebagaimana yang dikemukakan oleh Soehino berikut: Negara kesatuan itu adalah negara yang tidak tersusun dari beberapa negara, melainkan hanya terdiri atas satu negara, sehingga tidak ada suatu negara di dalam negara. Dengan demikian dalam negara kesatuan hanya ada satu pemerintah, yaitu pemerintah pusat yang mempunyai kekuasaan serta wewenang tertinggi ada dalam bidang pemerintahan negara, menetapkan kebijaksanaan pemerintahan dan melaksanakan pula pemerintahan negara baik di pusat maupun di daerahdaerah (Soehino, 2000:224).

Secara teoritik maupun yuridis desentralisasi fiskal dapat juga dilakukan oleh pemerintah pusat sebagai konsekuensi dari diberlakukannya sistem otonomi daerah di Indonesia. Hal ini tidak lain ditujukan untuk kesejahteraan masyarakat di daerah itu sendiri. Kekhawatiran mengenai dampak bagi bentuk negara kesatuan yang akan luntur adalah sesuatu yang tidak rasional dikarenakan kekuasaan pemerintahan tetap berada di tangan pemerintah pusat. Selama pengaturan yang jelas mengenai apaapa saja yang menjadi kewenangan pemerintah daerah dalam urusan keuangan dan pemerintah pusat tetap memegang kendali kunci dalam urusan keuangan tersebut, maka konsep negara kesatuan yang telah kita anut selama ini akan tetap utuh. 
Jenis-Jenis Pajak yang Didesentralisasikan oleh Pemerintah Pusat ke Pemerintahan Daerah

Dengan adanya otonomi di daerah, maka akan berimplikasi langsung terhadap kebutuhan-kebutuhan dana yang sangat besar. Untuk itu, pemerintahan daerah diberikan sumber-sumber-sumber pendapatan (keuangan) yang berfungsi sebagai instrumen untuk menjalankan semua urusan yang menjadi kewenangan daerah. Penyelenggaraan fungsi pemerintahan daerah akan berjalan secara optimal apabila diikuti dengan pemberian sumber-sumber penerimaan (keuangan) yang cukup kepada daerah dengan mengacu kepada peraturan perundang-undangan.

Sejalan dengan adanya pembagian-pembagian kewenangan atau urusan-urusan, maka pendanaan daerah dilakukan berdasarkan asas desentralisasi, dekonsentrasi, dan tugas pembantuan. Pendanaan penyelenggaraan pemerintahan berdasarkan asas desentralisasi dan dilakukan atas beban Anggaran Pendapatan dan Belanja Daerah (yang selanjutnya akan disebut APBD), pendanaan penyelenggaraan pemerintahan berdasarkan atas asas dekonsentrasi dilakukan atas dasar beban Anggaran Pendapatan dan Belanja Negara (yang selanjutnya disebut APBN), dan pendanaan terhadap penyelenggaraan pemerintahan tersebut berdasarkan atas tugas-tugas pembantuan dilakukan atas beban anggaran tingkat pemerintahan yang menugaskan.

Dalam rangka penyelenggaraan pemerintahan dan pelayanan kepada masyarakat yang berdasarkan asas desentralisasi, daerah akan diberikan wewenang untuk memungut pajak atau retribusi daerah (tax assignment) dan pemberian bagi hasil penerimaan (revenue sharing) serta bantuan keuangan (financial granting) atau dikenal sebagai dana perimbangan sebagai sumber dana bagi APBD.

Peraturan Pemerintah Nomor 58 Tahun 2005, tentang Pengelolaan Keuangan Daerah (selanjutnya disebut PP No. 58 Tahun 2005) menyatakan bahwa keuangan daerah adalah semua hak dan kewajiban daerah dalam rangka penyelenggaraan pemerintah daerah yang dapat dinilai dengan uang termasuk di dalamnya segala bentuk kekayaan daerah tersebut. Dari definisi di atas, maka menurut Pasal 2 PP No. 58 Tahun 2005 dinyatakan bahwa ruang lingkup keuangan daerah adalah sebagai berikut: hak daerah untuk memungut pajak daerah dan retribusi daerah serta melakukan pinjaman; kewajiban daerah untuk menyelenggarakan urusan-urusan di pemerintahan daerah dan membayar tagihan pada pihak ketiga; penerimaan daerah; pengeluaran daerah; kekayaan daerah yang dikelola sendiri atau oleh pihak lain berupa uang, surat berharga, piutang, barang, serta hak-hak lain yang dapat dinilai dengan uang, termasuk kekayaan yang dipisahkan pada perusahaan daerah; kekayaan pihak lain yang dikuasai oleh pemerintah daerah dalam rangka penyelenggaraan tugas-tugas pemerintahan daerah dan/atau kepentingan umum.

Sedangkan menurut Keputusan Menteri Dalam Negeri Nomor 29 Tahun 2002 yang sekarang berubah menjadi Permendagri Nomor 13 Tahun 2006 tentang Pedoman Pengurusan, Pertanggungjawaban dan Pengawasan Keuangan di Daerah serta Tata Cara Penyusunan Anggaran Pendapatan Belanja Daerah, dinyatakan bahwa keuangan daerah adalah semua hak dan kewajiban daerah dalam rangka penyelenggaraan pemerintah daerah yang dapat dinilai dengan uang termaksud di dalamnya segala bentuk kekayaan yang berhubungan dengan hak dan kewajiban daerah, di dalam kerangka anggaran pendapatan dan belanja daerah.

Menurut Halim, keuangan daerah sebagai semua hak dan kewajiban yang dapat dinilai dengan uang, demikian pula segala sesuatu baik yang berupa uang maupun barang yang dapat dijadikan kekayaan daerah sepanjang itu belum dimiliki atau belum dikuasai oleh Negara atau daerah yang lebih tinggi serta pihak-pihak lain sesuai ketentuan atau peraturan undang-undang yang berlaku (Abdul Halim, 2004:20). Senada dengan Halim, Mamesah menyatakan bahwa keuangan daerah dapat diartikan sebagai semua hak dan kewajiban yang dapat dinilai dengan uang, demikian pula segala sesuatu baik berupa uang maupun barang yang dapat dijadikan kekayaan daerah sepanjang belum dimiliki oleh negara atau oleh daerah yang lebih tinggi serta pihak-pihak lain sesuai peraturan perundangan yang berlaku (Anonim, Reformasi Manajemen Keuangan Daerah, http://google.com, diakses pada tanggal 29 Juni 2012). Dari defenisi tersebut, selanjutnya Halim menyatakan terdapat 2 (dua) hal yang perlu dijelaskan, yaitu Pertama, yang dimaksud dengan hak adalah hak untuk memungut sumber-sumber penerimaan daerah seperti pajak daerah, retribusi daerah, hasil perusahaan milik daerah, dan lain-lain, dan atau pun hak untuk menerima sumber-sumber penerimaan lain seperti Dana Alokasi Umum dan Dana Alokasi Khusus sesuai dengan peraturan yang ditetapkan. Hak tersebut akan menaikkan kekayaan daerah, dan Kedua, yang dimaksud dengan semua kewajiban adalah kewajiban-kewajiban untuk mengeluarkan uang untuk membayar tagihan-tagihan kepada daerah dalam rangka penyelenggaraan fungsi pemerintahan, infrastruktur, pelayanan umum, dan pengembangan ekonomi (Abdul Halim, 2004:20). 
Adapun ruang lingkup keuangan daerah menurut Halim ada dua yaitu: Pertama, Keuangan daerah yang dikelola langsung, meliputi ABPD dan barang-barang inventaris milik daerah. Kedua, Kekayaan daerah yang dapat dipisahkan, meliputi Badan Usaha Milik Daerah (BUMD) Keuangan daerah dikelola melalui manajemen keuangan daerah (Abdul Halim, 2004: 20).

Pengertian keuangan daerah menurut Bahrullah Akbar adalah semua hak dan kewajiban daerah dalam rangka penyelenggaraan pemerintahan daerah yang dapat dinilai dengan uang, termasuk di dalamnya segala bentuk kekayaan yang berhubungan dengan hak dan kewajiban daerah, dalam kerangka APBD (Bahrullah Akbar, 2002). Dari definisi keuangan daerah tersebut melekat 4 (empat) dimensi: Adanya dimensi hak dan kewajiban; Adanya dimensi tujuan dan perencanaan; Adanya dimensi penyelenggaraan dan pelayanan publik; dan Adanya dimensi nilai uang dan barang (investasi dan inventarisasi).

Untuk membiayai semua urusan yang menjadi wewenangnya, daerah pasti memiliki sumber-sumber dana (keuangan) antara lain, Pendapatan Asli Daerah (yang selanjutnya disebut PAD) yaitu: hasil pajak daerah; hasil retribusi daerah; hasil pengelolaan kekayaan daerah yang dipisahkan; dan lain-lain PAD yang sah; serta Dana Perimbangan dan Pendapatan daerah yang sah sesuai dengan Pasal 157 UU No. 32 Tahun 2004.

Sedangkan penerimaan di daerah menurut Pasal 5 UU No. 33 Tahun 2004 terdiri dari: Penerimaan daerah dalam rangka desentralisasi terdiri atas Pendapatan Daerah dan Pembiayaan terdiri dari: a. Pendapatan Asli Daerah; b. Dana Perimbangan; dan c. Lain-lain Pendapatan; Pembiayaan yang bersumber dari: a. Sisi lebih perhitungan anggaran daerah; $b$. Penerimaan pinjaman daerah; c. Dana cadangan daerah; dan d. Hasil penjualan kekayaan daerah yang dipisahkan.

Berdasarkan ketentuan Pasal 157 UU No. 32 Tahun 2004, maka pajak merupakan salah satu sumber pendapatan daerah, maka menandakan bahwa telah terjadi desentralisasi fiskal. Artinya bahwa daerah diberikan kewenangan untuk menentukan norma, standar, prosedur dan ketentuan mengenai penarikan pajak dari masyarakat. Secara normatif yuridis, hal tersebut nampak bertentangan dengan Pasal 10 ayat (3) UU No. 32 Tahun 2004, namun demikian jika dilihat dari sisi yang lain akan membantu daerah utuk menyelenggakan otonomi dengan efektif dan efisien. Otonomi membutuhkan dana yang sangat besar sehingga kebijakan fiskal dalam artian pemungutan pajak oleh daerah harus diakomodir.
Supaya pemungutan pajak oleh daerah-daerah tidak bertentangan dengan ketentuan Pasal 10 ayat (3) UU No. 32 Tahun 2004, maka kewenangan daerah tersebut ditentukan secara limitatif mengenai jenis pajak yang dipungut dan prosentase maksimal yang diperbolehkan. Karenanya telah ditetapkan UU No. 28 Tahun 2009 sebagai tindak lanjut dari ketentuan Pasal 158 UU No. 32 Tahun 2004.

Melalui UU No. 28 Tahun 2009 tersebut, maka telah ditentukan pula mengenai apa saja yang dapat dijadikan objek pajak daerah atau apa saja jenisjenis pajak daerah. Pasal 2 UU No. 28 Tahun 2009 menentukan jenis objek pajak aerah sebagai berikut: Pertama, Jenis Pajak Propinsi terdiri atas: Pajak Kendaraan Bermotor; Bea Balik Nama Kendaraan Bermotor; Pajak Bahan Bakar Kendaraan Bermotor; Pajak Air Permukaan; dan Pajak Rokok. Kedua, Jenis Pajak Kabupaten atau Kota terdiri atas: Pajak Hotel; Pajak Restoran; Pajak Hiburan; Pajak Reklame; Pajak Penerangan Jalan; Pajak Mineral Bukan Logam dan Batuan; Pajak Parkir; Pajak Air Tanah; Pajak Sarang Burung Walet; Pajak Bumi dan Bangunan Pedesaan dan Perkotaan; dan Bea Perolehan Hak atas Tanah dan Bangunan.

Ketentuan Pasal 2 UU No. 28 Tahun 2009 di atas adalah bersifat limitatif. Sehingga daerah tidak dapat membuat objek pajak atau jenis pajak di luar apa yang ditentukan oleh Pasal 2 di atas. Hal ini bertujuan supaya daerah tidak membuat objek pajak sesuai dengan hasrat dan keinginannya sendiri-sendiri. Pemerintah daerah hanya diberikan wewenang untuk memungut pajak daerah seperti ketentuan pasal di atas. Serta pemerintah daerah memiliki kewajiban untuk membuat Peraturan Daerah tentang jenis-jenis pajak di atas.

\section{PENUTUP \\ Kesimpulan}

Pelaksanaan desentralisasi fiskal tidak akan membawa dampak negatif terhadap konsep negara kesatuan yang dianut di negara Indonesia, hal tersebut dikarenakan kekuasaan pemerintahan tertinggi tetap di tangan pemerintah pusat, dan pemerintah pusat berwenang untuk mengatur daerah. Jika pelaksanaan desentralisasi fiskal dapat diselenggarakan dan dikelola dengan baik oleh suatu daerah otonom, maka akan membawa dampak yang baik dari daerah itu yaitu akan terwujudnya kesejahteraan masyarakat dan terselenggaranya semua urusan pemerintahan daerah dengan baik. Jenis pajak yang didesentralisasikan ke pemerintahan daerah adalah terdapat dalam ketentuan Pasal 2 UU No. 28 Tahun 2009. 


\section{Rekomendasi}

Untuk pemerataan pembangunan di daerah-daerah, sebaiknya pemerintah pusat tetap memegang kendali atas sumber-sumber pendapatan yang penting dan strategis, agar dapat diberikan ke daerah lain yang sumber pendapatannya masih minim. Hal ini juga untuk menjaga bentuk negara kesatuan yang telah kita anut.

\section{DAFTAR PUSTAKA}

\section{Buku:}

Astawa, I Gde Pantja, 2009, Problematika Hukum Otonomi Daerah di Indonesia Bandung: Alumni.

Gandjong, Agus Salim Andi, 2007, Pemerintahan Daerah Kajian Politik dan Hukum, Bogor: Ghalia Indonesia.

Hajdon, Philipus M., 2008, Pengantar Hukum Administrasi Indonesia, Yogyakarta: Gajah Mada University Press.

Hendratno, Edie Toet, 2009, Negara Kesatuan, Desentralisasi, dan Federalisme, Jakarta: Graha Ilmu dan Universitas Pancasila Press.

Huda, Ni'matul, 2005, Hukum Tata Negara Indonesia, Jakarta: Raja Grafindo Persada.

Lubis, M. Solly, 1983, Pergeseran Garis Politik dan Perundang-undangan mengenai Pemerintah Daerah, Bandung: Alumni.

Michael, Tomy, 2013, "Penerapan Hukum Kasih untuk Mengoptimalkan UU No. 11 Tahun 2009”, [DIALEKTIK] Jurnal Ilmiah Indonesia, Jilid I, April 2013.

Noer Fauzi dan R.Yando Zakaria, 2000, Mensiasati Otonomi Daerah. Yogyakarta: Konsorsium Pembaruan Agraria bekerjasama dengan INSIST Press.

Rahayu, Ani Sri, 2010, Pengantar Kebijakan Fiskal, Jakarta: Bumi Aksara.

Soehino, 2000, Ilmu Negara, Yogyakarta: Liberty.

Sujatmoko, Emanuel, 2010, Hubungan Keuangan Pusat dan Daerah, Diktat Kuliah Kebijakan Fiskal Magister Hukum Pemerintahan Fakultas Hukum Universitas Airlangga, Surabaya.

Sunarno, Siswanto, 2009, Hukum Pemerintahan Daerah di Indonesia, Jakarta: Sinar Grafika

Syafruddin, A., 1991, Titik Berat Otonomi Daerah pada Daerah Tingkat II dan Perkembangannya, Bandung: Mandar Maju.

Widjaya, H.A.W., 2005, Penyelenggaraan Otonomi Daerah di Indonesia, Jakarta: Rajawali Pers
Winarsih, Sri, 2010, Sistem Otonomi Daerah, Diktat Kuliah Magister Hukum Pemerintahan, Surabaya: Fakultas Hukum Universitas Airlangga.

Yamin, Moh., 1960, Proklamasi dan Konstitusi Republik Indonesia, Cetakan IV, Jakarta: Djambatan.

Yustika, Ahmad Erani, 2008, Desentralisasi Ekonomi di Indonesia Kajian Teoritis dan Realitas Empiris. Malang: Bayumedia.

\section{Peraturan Perundang-undangan:}

Undang-Undang Dasar 1945.

Undang-Undang Nomor 18 Tahun 1997 tentang Pajak Daerah dan Retribusi Daerah.

Undang-Undang Nomor 34 Tahun 2000 tentang Perubahan atas Undang-Undang Nomor 18 Tahun 1997 tentang Pajak Daerah dan Retribusi Daerah.

Undang-Undang Nomor 32 Tahun 2004 tentang Pemerintahan Daerah.

Undang-Undang Nomor 33 Tahun 2004 tentang Perimbangan Keuangan antara Pemerintah Pusat dan Pemerintah Daerah.

Undang-Undang Nomor 28 Tahun 2009 tentang Pajak Daerah dan Retribusi Daerah.

Peraturan Pemerintah Nomor 66 Tahun 2001 tentang Retribusi Daerah.

Peraturan Pemerintah Nomor 58 Tahun 2005 tentang Pengelolaan Keuangan Daerah.

Peraturan Pemerintah Nomor 38 Tahun 2007 tentang Pembagian Urusan Pemerintahan antara Pemerintah Pusat, Pemerintahan Daerah Propinsi, dan Pemerintahan Daerah Kabupaten/Kota.

Keputusan Menteri Dalam Negeri Nomor 29 Tahun 2002 tentang

Permendagri Nomor 13 Tahun 2006 tentang Pedoman Pengurusan, Pertanggungjawaban dan Pengawasan Keuangan Daerah serta Tata Cara Penyusunan Anggaran Pendapatan Belanja Daerah.

\section{Website:}

http://www.fiskal.depkeu.go.id/2010, diunduh tanggal 27 Agustus 2013.

http://www.artikata.com, diunduh tanggal 27 Agustus 2013.

http://www.organisasi.go.id//Pengertian Kebijakan Moneter dan Fiskal//, diunduh tanggal 27 Agustus 2013.

Anonim, Reformasi Manajemen Keuangan Daerah, http://google.com, diakses tanggal 29 Juni 2012. 